\title{
Biology and Management of Insect Pests in North American Intensively Managed HaRDWOOd ForEST SYSTEMS 1
}

\section{David R. Coyle, ${ }^{1,2}$ T. Evan Nebeker, ${ }^{3}$ Elwood R. Hart, ${ }^{4}$ and William J. Mattson ${ }^{5}$}

${ }^{1}$ USDA Forest Service, Southern Research Station, New Ellenton, South Carolina 29809

${ }^{2}$ Cur rent address: Department of E ntomology, University of Wisconsin, Madison, Wisconsin 53706; email: dcoyle@ entomology.wisc.edu

${ }^{3}$ Department of Entomology and Plant Pathology, Mississippi State University, Mississippi State, Mississippi 39762; email: enebeker@ entomology.msstate.edu ${ }^{4}$ Departments of Entomology and Forestry, lowa State University, Ames, I owa 50011; email: ehart@iastate.edu

${ }^{5}$ USDA Forest Service, North Central Research Station, Forestry Sciences Laboratory, Rhinelander, Wisconsin 54501; email: wmattson@ fs.fed.us

K ey Wor ds defoliators, integrated pest management, sap-feeders, short-rotation forestry, stem borers

Abstract Increasing demand for wood and wood products is putting stress on traditional forest production areas, leading to long-term economic and environmental concerns. Intensively managed hardwood forest systems (IMHFS), grown using conventional agricultural as well as forestry methods, can help alleviate potential problems in natural forest production areas. Although IMHFS can produce more biomass per hectare per year than natural forests, the ecologically simpliped, monocultural systems may greatly increase the cropō susceptibility to pests. Species in the genera Populus and Salix comprise the greatest acreage in IMHFS in North A merica, but other species, including Liquidambar styracißua and Platanus occidentalis, are also important. We discuss life histories, realized and potential damage, and management options for the most economically inßuential pests that affect these hardwood species. The substantial inherent challenges associated with pest management in the monocultural environments created by IMHFS are reviewed. Finally, we discuss ways to design IMHFS that may reduce their susceptibility to pests, increase their growth and productivity potential, and create a more sustainable environment.

\footnotetext{
*The U.S. Government has the right to retain a nonexclusive, royalty-free license in and to any copyright covering this paper.

${ }^{1}$ Mention of a commercial or proprietary product does not constitute endorsement or recommendation by the USDA Forest Service, Mississippi State University, or lowa State University for its use.
} 


\section{INTRODUCTION}

Since the mid-twentieth century a doubling of the human population and rising wealth and environmental consciousness in North America have increased human demands on and changed perceptions of forest resources and their management. Five major changes promise to continue to drive forest management practices in new directions: $(a)$ increasing numbers of private owners in forested landscapes and $(b)$ increasing public concerns for improving the health and preservation of forests for both recreation and conservation purposes are constraining traditional timber harvesting on publicly and privately owned forests; $(c)$ everrising transportation costs for moving raw materials necessitate a closer proximity of wood resources to their points of processing and utilization; $(d)$ new end uses for wood resources are evolving that will demand new production methodologies; and (e) increased afforestation and reforestation for the sequestration of atmospheric $\mathrm{CO}_{2}$ to obtain carbon credits by industry and government will depend heavily on plantation culture.

One production strategy that addresses these changing perspectives and needs is intensively managed hardwood forest systems (IMHFS) on land considered marginal for agriculture and closer to wood processing facilities. In many ways, these systems share as much in common with agronomy as with traditional forestry. Although these systems have been labeled variously as intensive-culture forestry, short-rotation forestry, biomass forestry, and agroforestry, we believe that the term IMHFS better describes these systems.

Several common characteristics define IMHFS in North America: $(a)$ use of an inherently fast-growing angiosperm tree species; $(b)$ low genetic diversity among plantings, sometimes being monoclonal populations; $(c)$ genetically improved stock characterized by rapid growth, typically chosen to match specific sites; $(d)$ short rotation cycles, usually 3 to 12 years between harvests; $(e)$ controlled spacing to assure optimum yield and permit the use of mechanized management and harvesting techniques; and $(f)$ use of typical agronomic practices, including site preparation, fertilization, weed and pest control, pest surveillance and management programs, whole-plant harvesting, and sometimes, irrigation (138).

The primary end uses for trees grown in IMHFS include pulp for paper production, engineered wood products, chemicals from wood, and biofuels. In addition, some IMHFS may grow sufficiently fast and have desirable characteristics for sawtimber (trees with at least an 11-inch diameter at breast height and from which at least one 12- or two 8-foot noncontiguous sawlogs can be produced). Other important products of these plantings can include agroforestry applications and ecological services such as wind, water, temperature amelioration, pollution control, carbon sequestration, waste disposal, wildlife habitat, snowfences, and site reclamation.

Aside from loblolly pine (Pinus taeda L.), longleaf pine (Pinus palustris Miller), and slash pine (Pinus elliottii Engelm.), most intensive forest management research and development over the past 50 years in North America has been limited to 
several species of hardwoods. Two genera of the Salicaceae, Populus (cottonwoods, aspens, and poplars) and Salix (willows), have been the primary focus. Efforts also have been invested into developing Liquidambar styraciflua and Platanus occidentalis for IMHFS. To a lesser degree, other genera have been considered, including Paulownia, Robinia, Juglans, Alnus, Eucalyptus, Quercus, Fraxinus, Liriodendron, and Acer (7a, 10a, 49a).

Intensive culture research through the 1970s focused on breeding and selection for increased growth, especially with Populus and Salix. By the early 1980s, it had become obvious through some spectacular failures, caused by both insect and pathogen pests, that a more holistic approach was necessary. Traditional integrated pest management (IPM) approaches, as used in annual cropping systems, were difficult to apply for several reasons: (a) trees, being a longer-term crop, have all the economic uncertainties associated with traditional forest management; (b) the major pest complexes were for the most part unidentified; and (c) many of the identified arthropod pest species are multivoltine, each generation having a slightly different impact each year on the perennial host.

Our collective knowledge of pest management in IMHFS is not yet well developed, but considerable progress has been made in the past 25 years. Here we review the major arthropod pests in the most important IMHFS and provide current information on IPM strategies. We limit the scope of this review to arthropod pests and interactions among these pests. In certain geographic areas pathogens are more limiting to IMHFS than arthropods, particularly in the case of Melampsora leaf rust on Populus in the Pacific Northwest (103). In other cases interactions between insects and pathogens, in part, regulate the use of certain tree species and cultivars in IMHFS. For example, bacterial leaf scorch, Xylella fastidiosa, vectored by leafhoppers (Hemiptera: Cicadellidae), is largely responsible for limiting the utility of sycamore in the South (79). In the Lake States mite and beetle herbivory increases susceptibility of certain Populus selections to Septoria musiva foliar fungus (73). In addition, we limit the geographic range of our review to the continental United States and Canada and focus only on hardwood species on which large-scale attempts are being made to facilitate their use in IMHFS for timber, biofuel, or wood products.

\section{MAJOR NORTH AMERICAN REGIONAL PRODUCTION AREAS}

The feasibility of IMHFS has been widely explored in both the United States and southern Canada. In all regions, the management of key insect and pathogen pests is critical to the successful development of IMHFS. In some instances, pests have been the limiting factor to IMHFS utilization. For example, silver maple (Acer saccharinum L.) has been evaluated in the north-central United States where trials showed promise, but a combination of pests quickly tempered early enthusiasm. Among the most serious was the flatheaded appletree borer, 
Chrysobothris femorata (Olivier) (Coleoptera: Buprestidae), which caused stem girdling ("girdling" is a type of damage whereby the cambium is eaten or scraped off the entire circumference around the stem or branch, rendering it unable to transport water and nutrients) and over $40 \%$ mortality of first-year trees (E.R. Hart, unpublished data). Alders (Alnus spp.) were considered a promising group for IMHFS because of the rapid growth rates and symbiotic nitrogen-fixing capabilities of certain species and hybrids (48). However, the European alder leafminer, Fenusa dohrnii (Tischbein) (Hymenoptera: Tenthredinidae), is an important defoliating pest of Alnus, and defoliation levels have eclipsed 50\% in experimental and pilot plantations (51). Several pests, including borers (108) and psyllids (32), contributed to discouraging the use of Eucalyptus species and hybrids in IMHFS in California.

The southeastern United States (including eastern Texas) has the longest history of research into the employment of IMHFS, where there were nearly 12,000 ha established in 1995; within a few years this land area was expected to grow to over 27,000 ha (77). Eastern cottonwood, sweetgum, and sycamore currently are the predominant hardwood species in commercial IMHFS. Eucalyptus is grown in IMHFS in Florida (125).

Likewise, in the northeastern United States and southeastern Canada, several decades of research on and the development of IMHFS have mostly focused on Populus and Salix selections. Several thousand hectares are currently in production $(76,153)$. Willows, in particular, show considerable promise as a woody biomass crop because of their high productivity after coppice (76). Fast-growing selections are planted using agricultural practices, and aboveground biomass is harvested after the first year to promote multiple-stemmed regrowth (2). Thereafter, willow plantations are harvested on 3- to 4-year cycles for up to seven rotations, with the primary end uses being biofuels (2).

In the northcentral United States and southcentral Canadian provinces, nearly all work has concentrated on Populus, with some attention to Salix in northern localities and Alnus in southern localities $(34,48,117)$. While the possibility of using this fuel production to operate cofired power plants (burning plant biomass in conjunction with coal) or combined heat and power plants (burning plant biomass directly) remains an option, most of the crop goes toward pulp and paper production. However, over 6800 ha of poplar and willow are needed to fuel a new combined heat and power plant in Minnesota. In this region rotation cycles for Populus are generally 10 to 12 years (117), and those for Alnus are at least 8 years (48).

Research on IMHFS has focused on Populus in the northwestern United States and southwestern Canadian provinces. Altogether more than 25,000 ha are in commercial Populus production in Washington, Idaho, Oregon, and British Columbia $(21,113,137)$. Approximately 1200 ha, with a value of over $\$ 8$ million, are harvested annually for pulp (21). Increasing rotation times and pruning have enabled growers to use intensively managed Populus for pulp, paper, and sawtimber (137). Little work with IMHFS occurs in the southwestern United States. Populus has received some attention in Arizona, as has Eucalyptus in California (126a). 


\section{THE SPECIAL CHALLENGES OF INTENSIVELY MANAGED HARDWOOD FOREST SYSTEMS: PEST-PRONE SYSTEMS BY DESIGN}

Cropping systems are highly pest prone for many reasons, of which simplicity (low biodiversity) and spatial uniformity are key. It is axiomatic that increasing the abundance (increased density and geographic area) of a plant species increases the number of insects associated with it $(78,104)$. This in itself is not necessarily detrimental from a crop production perspective, but it is also evident that increasing plant abundance leads to increased insect population levels, even periodic outbreaks, of some species (47). Many eruptive herbivores, nearly everywhere in the world, are linked to monocultures or near-monocultures, i.e., in which most plants in a stand or landscape are highly suitable hosts for the particular outbreak species (90). We do not imply that all low-diversity stands and landscapes generate eruptive insect populations, but that monocultures and near-monocultures (defined by the insect's host range) are a critical and necessary, but not fully sufficient, condition for insect outbreak development.

Stand location is one factor that can increase the pest susceptibility of IMHFS compared with natural monoclonal stands. IMHFS are generally planted on marginal land where populations of those hardwood species would not naturally occur, thereby reducing natural biological control mechanisms. The mechanisms underlying increased pest outbreaks with respect to simplicity and uniformity rest with reduced mortality from $(a)$ natural enemies, $(b)$ phenological asynchrony with host plants, $(c)$ plant defenses, and $(d)$ dispersal losses while feeding and host-seeking. Moreover, the larger the cropping area, the greater the potential for large pest populations, and the lower the probability that the populations will be driven to near extinction by stochastic factors. The simple environments created by IMHFS may also make them susceptible to invasion by exotic species (150), such as the gypsy moth, Lymantria dispar L. (Lepidoptera: Lymantriidae), particularly from reduced natural enemy populations and abundant hosts.

The purposeful breeding of and selection for the fastest-growing plant cultivars further contributes to the pest susceptibility of most cropping systems. If breeding starts with hybridizing two or more desirable species, as is often the case, it can inadvertently lead to the erosion of the natural defenses that are inherent in the parental stock, unless great care is taken to retain or amplify the natural resistance $(41,85)$. Often the fastest-growing progeny are by their very nature highly nutrient and light demanding and therefore nutrient rich (and sometimes defense poor), thereby providing pests with salubrious, more optimal diets $(20,59)$. Moreover, planting on rich soils and/or fertilizing can further contribute to enhancing food quality, survival, growth, and reproduction of pests $(44,58,60)$. In addition, fastgrowing hardwood species, especially Populus and Salix, are particularly suitable for and susceptible to pests during their first 3 years. Their canopies are highly homogeneous because a high percentage of the foliage is a fast-growing morphotype, 
generated by long, indeterminate shoots that produce leaves with high water and nutrient content and relatively low fiber concentrations (84a). This type of foliage is highly preferred by many folivores and typically permits rapid insect growth and high fecundity.

Because research on IMHFS is still in its infancy, and IMHFS are still expanding in acreage, not all potential pests have been discovered and evaluated. Until recently, the cottonwood leafcurl mite, Tetra lobulifera (Keifer) (Acari: Eriophyidae), had not been reported as a significant pest of plantation Populus (24). As a result, when outbreak populations developed, no IPM strategy existed for this pest, forcing growers to use chemical pesticides for its management (24). As hardwood plantations age, problem pests may also change. For example, in intensively managed Populus systems the cottonwood leaf beetle, Chrysomela scripta F. (Coleoptera: Chrysomelidae), is unequivocally the major arthropod pest of young trees. This beetle can have up to five generations per year in the South and is a pest throughout a plantation's existence. But as trees age a smaller proportion of the crown is composed of succulent, long-shoot foliage preferred for C. scripta feeding (8); therefore the impacts may decline to negligible levels in large trees. Because production and protection costs have to be compounded over the life of the crop investment, growers have a strong incentive to minimize costs, thereby providing challenges to discover low-cost, high-efficacy pest management tools. Chemical pesticides are often chosen because they are relatively cheap and effective. Little is yet known about the economic injury levels for most pests, further complicating sound pest management.

Because biomass production has been a primary focus for IMHFS, a disproportionate amount of effort has gone into growth potential and tree physiology research (19). Consequently, the growth potential of some tree species under intensive management is truly amazing; for instance, some Populus clones have exhibited aboveground biomass production rates of $35 \mathrm{Mg}^{-1} \mathrm{ha}^{-1}$ year ${ }^{-1}$ (127). However, advances in pest management need to catch up with the advances in plant production.

\section{HARDWOOD TREE GENERA AND THEIR MOST IMPORTANT ARTHROPOD PESTS}

\section{Populus: Cottonwoods, Aspens, Poplars, and Their Hybrids}

DEFOLIATORS C. scripta is probably the most widespread and significant defoliating insect pest of intensively managed Populus in North America (50). This native insect is distributed throughout the natural range of nearly all Populus species in the United States and Canada, and also has been reported in northern Mexico (13).

Beetles overwinter as sexually immature adults in leaf litter and on the ground both within and near plantations, and emerge from diapause in synchrony with 
Populus bud break. Newly active adults cluster on fresh foliage. After maturation feeding and mating, the adults disperse throughout the plantings and lay eggs in clusters of 30 to 80 , usually on the ventral surfaces of expanding leaves (52). A single adult is capable of laying over 1000 eggs during her lifetime (30). After hatching, neonates graze gregariously on the leaf epithelium. Second and third instars move onto adjacent leaves as necessary and feed less gregariously as they age, consuming all areas of the leaf except large veins. Prepupal larvae move downward on the branches and pupate either on low branches or ground cover. There may be as few as one or as many as seven generations per year in the northern and southern regions, respectively (56). In central Iowa, warmer and extended growing seasons recently increased the number of annual generations observed from three (1989-1996) to four (1997-2000) (89). Thermal requirements for development from egg to adult have been reported to range from 230 to 280 days $(67,102)$.

Nearly all feeding by both larvae and adults occurs on the youngest 8 to 10 leaves on a shoot (8). Because of Populus' indeterminate growth patterns, younger trees have a high percentage of their foliage in this stage during the growing season; as trees age and growth patterns change, the percentage of susceptible foliage changes. Thus, young Populus plantations are particularly susceptible to C. scripta damage. Low artificial defoliation levels can induce compensatory growth, whereby Populus trees actually increase in size (116). However, defoliation levels of $75 \%$ or more significantly decreased tree growth (116). One study showed that natural C. scripta defoliation reduced tree volume of certain Populus clones over $70 \%$ after three growing seasons (27).

Studies in Iowa found second-generation $C$. scripta to be the most damaging to plantation Populus because of a lack of natural enemy control (37). During this generation, the economic injury levels for C. scripta ranged from 0.2 to 0.9 egg masses per actively growing terminal (38). Given C. scripta's reproductive potential and multivoltine nature, the economic threshold for plantation Populus is often easily surpassed.

The genus Populus is divided into six taxonomically distinct sections (33), all of which can interbreed. The primary hosts for C. scripta are from the sections Aigeiros and Tacamahaca (89). Intra- and intersectional hybrids also are susceptible, as are some Salix selections (13). Species of the section Populus usually are not considered hosts for the insect, although recent observations in west-central Minnesota indicate that some hybrids from this section are susceptible under heavy outbreak conditions (89).

Clonal susceptibility to $C$. scripta varies greatly, but several patterns are evident. Clones having white poplar (Populus alba L.) parentage are generally not preferred for feeding or oviposition by adult $C$. scripta $(14,50,52)$. Unfortunately, $P$. alba does not possess many of the desired growth or wood characteristics of other Populus species. Rapidly growing clones, such as those with $P$. trichocarpa and especially $P$. deltoides parentage, are much more preferred for adult $C$. scripta feeding and oviposition $(8,14,50,52)$. Within these clones, all of which are part of either Aigeiros or Tacamahaca sections, there is considerable variation. Clones 
having Aigeiros or Tacamahaca parentage had from 5\% to over 70\% defoliation in one Iowa study (14). Hybrid clones generally showed intermediate levels of defoliation susceptibility when compared with parent selections: Pure Aigeiros and Tacamahaca section clones had $37 \%$ and $76 \%$ defoliation, respectively, whereas hybrids had between 33\% and 54\% defoliation in southern Wisconsin (50). Similarly, adult $C$. scripta defoliation and oviposition were greater on clones having higher proportions of Aigeiros parentage than on clones having higher proportions of Tacamahaca parentage $(8,52)$. Thus far, only one study has attempted to correlate adult oviposition preference with larval development time (52). High correlations between the two parameters were found, which suggest that adult C. scripta preferentially oviposit on good food sources for their larvae. This finding has important implications, as larval development can be greatly influenced by clonal material $(4,26)$. In addition to poorer $C$. scripta larval development on clones with high proportions of Tacamahaca parentage, interyear variation in environmental characteristics can significantly influence larval development (26).

Nitrogen is often a limiting factor for arthropod development $(88,128)$. Adult C. scripta respond positively, via increased leaf area consumption, to increased foliar $\mathrm{N}$ content in the laboratory (146). This is important in the context of IMHFS, as fertilizer amendments that are often applied to promote rapid tree growth and development can exacerbate $C$. scripta damage (138). Both foliar nutritional factors (N content) and phenolic glycoside content affect C. scripta biology. Phenolic glycoside concentrations vary among Populus selections and leaf age classes (9). Younger Populus leaves have higher glycoside concentrations than older leaves, presumably as defensive chemical compounds. Several chemicals were discovered in epicuticular waxes that act as phagostimulants to adult C. scripta (82). These long-chain alcohols, in specific ratios, act synergistically with $\alpha$-tocopherylquinone to elicit a biting response in adult $C$. scripta. Phagostimulant levels vary among Populus selections $(29,83)$ and help explain adult feeding preferences (83). Larval feeding preferences are not explained by foliar phagostimulant amounts; however, a general seasonal decline exists for both larval performance (26) and leaf surface phagostimulant content (29).

The question remains: How can we effectively manage $C$. scripta populations in Populus plantations in a manner that does not induce significant ecological perturbations? We believe that effective management can be accomplished by using several methods synchronously (28) in conjunction with the native natural enemy complex $(7,67)$. Several Bacillus thuringiensis strains and toxins are lethal to C. scripta $(40,66,154)$. Two commercial B. thuringiensis formulations, Novodor ${ }^{\circledR}$ (subsp. tenebrionis) and Raven ${ }^{\circledR}$ (subsp. kurstaki), provide excellent control of C. scripta larvae (31). Unfortunately, these biorational chemicals are costly, and Raven ${ }^{\circledR}$ is no longer available on the open market (T. Johnson, personal communication).

Transgenic Populus selections have been created carrying either a $B$. thuringiensis toxin gene (140) or a proteinase inhibitor gene (74). Preliminary trials with the proteinase inhibitor transgenics have shown some insecticidal effects in plantlets 
(71), but activity was not evident as trees grew past the earliest stages (D.R. Coyle, unpublished data). Using proteinase inhibitor genes as a management technique has potential, however, as researchers have successfully transformed Populus selections and demonstrated toxicity to Chrysomela tremulae larvae (80). Much literature exists regarding the pros and cons of using transgenic plants as pest management options (28, 140 and references therein). Synthetic chemicals remain an effective short-term option (1; D.R. Coyle, personal observation), but complete reliance on this method could lead to pesticide resistance, ecological disturbances, and eventual loss of this tool as a component of IPM plans (55).

Ultimately, planting resistant and susceptible clones, biorational and synthetic insecticides, and natural enemies all need to play a part in an effective IPM plan for C. scripta (28). Future research needs include IPM trials using the various control techniques in large-scale operations and continued screening for resistant Populus clones.

The forest tent caterpillar, Malacosoma disstria Hübner (Lepidoptera: Lasiocampidae), is one of the most widely distributed eruptive herbivores in North America. It has a wide host range and has been recorded feeding on 29 native forest tree and shrub species in Canada and the northern United States, but seems only to sustain outbreaks in stands of Populus where trembling aspen (P. tremuloides Michx.) and bigtooth aspen ( $P$. grandidentata Michx.) are principal components (114). M. disstria also feeds on balsam poplar (P. balsamifera L.) and some P. deltoides selections (123; D.J. Robison, personal communication). Evidence of clonal variation in aspen susceptibility to $M$. disstria may be indicative of variations in constitutive defenses mediated by both levels of proteins and phenolics (84).

Mated females deposit egg bands, consisting of 150 to 250 eggs, on small twigs in July. Neonates overwinter within the egg band and emerge around budbreak. Delays in hatching relative to budbreak decrease larval survival rates (111). Larvae mine developing buds (65) and survive on ramets of later flushing clones. Larvae feed gregariously for the first three instars, returning to a silken mat between feeding bouts. Fourth instars become solitary and typically wander off the mother tree, even if most of the foliage has not been consumed. Cocoons are spun between leaves and in crevices.

M. disstria population eruptions occur with roughly decadal frequency (39). Diseases and larval starvation certainly play a role in the collapse of most outbreaks, but it seems that pupal parasitoids are most probably responsible for population regulation (39). At endemic levels, predation of pupae by the Baltimore oriole (Icterus galbula L.) may be the factor responsible for maintaining low densities (110). The mechanisms of endemic population release from control by predation and parasitism remain unexplained.

Records dating from the beginning of the twentieth century suggest that outbreaks have been a constant problem in North America. In the last series of Canadian outbreaks the size of the areas involved peaked at 10.0, 12.8, and 13.0 million ha in Manitoba, Saskatchewan, and Alberta, respectively (18). Outbreaks seem to 
recur at 10- to 12-year intervals, lasting from 2 to 5 years in individual stands (90, 151).

Damage caused by severe $M$. disstria defoliation results in an immediate reduction in radial increment with a corresponding increase in stem mortality in subsequent years. Secondary pests further contribute to the reduction in stand yield, and stand decline may be further exacerbated by diseases such as hypoxylon canker [Hypoxylon mammatum (Wahlenb.) Karst.]. Low levels of M. disstria defoliation, however, can increase Populus production via compensatory growth (122).

Generally, intersectional Populus hybrids are less susceptible to M. disstria larval feeding than intrasectional clones (122). Larval $M$. disstria consumed the most foliage, gained the most weight, and had greater larval survival on a pure $P$. deltoides clone than on several hybrids (122). Section Populus hybrids are generally not preferred by $M$. disstria (122). Determining which clones are suitable for $M$. disstria development is a key step in effective IPM strategies. For instance, $M$. disstria populations increased over ninefold and decreased nearly threefold on preferred and nonpreferred Populus clones, respectively (123). Populus selections transformed with a $B$. thuringiensis toxin also exhibit toxicity toward lepidopteran pests $(95,121)$. Both $M$. disstria and $L$. dispar had reduced survival and consumed less leaf tissue on transgenic trees than on untransformed control trees (121), suggesting that generically modified hardwood selections could be a component in an IPM plan.

Since an outbreak in the early 1990s, the scented willow sawfly, Nematus salicisodoratus (Dyar) (Hymenoptera: Tenthredinidae), continues to be a major pest in intensively managed Populus in the Pacific Northwest $(21,144)$. At the peak of the outbreak in 1992 and 1993, commercial Populus plantations sustained between $10 \%$ and $100 \%$ defoliation (144). Three N. salicis-odoratus generations occur on Populus in the Pacific Northwest (144). Females lay a cluster of approximately 60 eggs on the underside of lower canopy leaves (144). The first two instars feed gregariously, leaving damage similar to that by larval C. scripta. Later instars become solitary feeders, consuming all but major leaf veins (144). Pupation occurs in the soil.

Considerable variation in $N$. salicis-odoratus host preference exists among Populus selections. $N$. salicis-odoratus consumed six times more foliage from a pure $P$. deltoides selection than from four other Populus hybrids (106). Two P. deltoides $\times P$. nigra hybrids also were evaluated, resulting in a substantial difference in the amount of foliage consumed between the two clones (106). In the Pacific Northwest, $P$. trichocarpa $\times P$. deltoides clones were severely defoliated (144). Clones containing $P$. maximowiczii parentage were not preferred in one study (106); however, no feeding preference was shown among several $P$. trichocarpa $\times$ $P$. maximowiczii and $P$. trichocarpa $\times P$. deltoides clones (144). This finding suggests that breeding resistant clones could prove challenging for this pest.

Broad-spectrum insecticides have been used successfully to reduce sawfly populations. Efforts have been made to document this pest's biology and develop an 
environmentally friendly IPM plan. Many parasitoids prey on N. salicis-odoratus, and a hymenopteran egg parasitoid (Anaphes spp.) was suspected of contributing greatly to the sawfly population collapse in 1994 (144). Natural enemies undoubtedly play a major role in the management of $N$. salicis-odoratus populations.

SAP-FEEDERS T. lobulifera is a sap-feeder whose damage causes leaf curling, loss of photosynthetic tissue, premature leaf abscission, and terminal mortality in intensively managed Populus $(24,107)$. Until recently, T. lobulifera had been recorded only in Mississippi, Ohio, South Dakota, and West Virginia (5). However, recent studies have identified $T$. lobulifera in five additional states and established its occurrence from the East to West Coast in both native and intensively managed forests $(24,25)$. P. grandidentata and six Populus hybrids are known hosts for T. lobulifera (25). Feeding damage can be exacerbated by the application of cultural treatments such as irrigation and fertilization (24).

T. lobulifera is an emerging pest, and little is known regarding its biology and impact on intensively managed Populus. Morris et al. (98) provide one of the few descriptions of $T$. lobulifera's life cycle. Mites emerge from diapause and begin feeding in the spring; hot, dry weather can induce rapid population increases. All life stages can be found together on foliage. Most mites die when leaves senesce, but some enter into diapause (J.W. Amrine, personal communication). However, one study examined 50 dormant cottonwood cuttings from trees with known $T$. lobulifera populations the previous summer and found no diapausing mites (25), emphasizing the paucity of data on the biology of this pest. The only effective control methods known are chemical (24). However, some Populus selections are resistant to T. lobulifera (R.J. Rousseau, personal communication) and may help combat the negative effects of this pest if deployed effectively (28).

The poplar leaf aphid, Chaitophorus populicola Thomas (Hemiptera: Aphididae), is an occasional pest of young cottonwood trees (132). Feeding takes place primarily near stem terminals, and aphid densities can exceed 500 aphids $\mathrm{cm}^{-1}$ of stem (132). Light infestations are common, but heavy infestations can result in significant damage. One aphid outbreak on a commercial plantation in Mississippi caused over $92 \%$ terminal mortality and an average terminal dieback of over 4 inches in yearling cottonwoods (132). To our knowledge, C. populicola feeds on $P$. deltoides clones only (132).

Pemphigus populitransversus Riley, the poplar petiolegall aphid, and P. nortoni Maxson (Hemiptera: Aphididae) are two gall-producing aphids that infest poplars $(46,70)$ and are frequently observed in Populus plantations (T.E. Nebeker, D.R. Coyle \& E.R. Hart, personal observation). Populus is the primary host of P. populitransversus with the secondary root hosts being Brassicaceae (70). P. nortoni is generally the less common of the two aphid species. Over $25 \%$ of leaves may be gall infested (70), but the resulting injury seldom affects tree growth rates.

During the summer of 2000 a new aphid pest of intensively managed Populus was discovered. Recently planted hybrid poplar cuttings were dying in a fiber farm in southeastern Missouri (101a). Cuttings with wilted, shriveled, and crinkled 
leaves had aphids on their roots, as did dead cuttings. Extracted healthy cuttings and dead or dying cuttings were compared and found to have a similar root structure. However, cuttings with the characteristic leaf symptoms had aphids associated with their roots, whereas aphids were not found on healthy cuttings. Aphids were found feeding at the base and along the sides of individual roots, and at the base of the cuttings in association with callus tissue that had formed as a result of the aphid injury. No other insects or pathogens were observed feeding or infecting the roots, stems, or leaves of the affected cuttings. P. populitransversus has not been reported from roots of Populus, and the root host for P. nortoni is unknown. However, the root injury caused by the subterranean aphid forms is remarkably similar to that inflicted on cruciferous hosts by $P$. populitransversus (70). Efforts are currently underway to identify this pest (S. Halbert, personal communication).

Management is not currently recommended, as natural enemies generally keep aphid populations under control. However, outbreak populations of C. populicola may require treatment with a broad-spectrum insecticide.

STEM BORERS The cottonwood twig borer, Gypsonoma hiambachiana (Kearfott) (Lepidoptera: Tortricidae), infests $P$. deltoides throughout its natural range. This multivoltine pest has two and up to five generations per year in Iowa (96) and the Mississippi Delta region (97), respectively. The life history and phenology of the insect have been described in the South $(97,112)$ and Midwest (96). Larval feeding causes a shortening of internodal distance and increased forking, stem and limb breakage, and mortality of terminal and lateral shoots, which can lead to loss of apical dominance, thus reducing tree growth and form $(131,139,151)$.

Host tree vigor does not seem to influence $G$. hiambachiana infestation and damage rates $(112,151)$, but a great deal of variation in resistance to G. hiambachiana exists among Populus selections. In Texas, native P. deltoides hybrids showed little resistance to $G$. hiambachiana attack $(112,151)$, but a nonnative hybrid was resistant. IMHFS in the Mississippi Delta showed geographic variation with respect to G. hiambachiana infestation levels, and adequate control was achieved with chemical insecticides (131). In Iowa, native $P$. deltoides clones showed a wide range of susceptibility, while clones with $P$. maximowitczii parentage were particularly susceptible (J.D. McMillin, E.E. Butin \& E.R. Hart, unpublished data). The best way to avoid damage is by planting resistant clones or using chemical control measures (23).

The poplar borer, Saperda calcarata Say (Coleoptera: Cerambycidae), lives primarily at and below the root collar zone in young trees and throughout the bole of larger trees (133). Damage is invariably more common in open than in dense stands and often increases along the edges of stands owing to the beetle's apparent preference for higher light conditions for oviposition. Adults emerge in late June, and begin ovipositing shortly thereafter; females cut crescent-shaped slits in the bark and insert eggs into the phloem. About 3 weeks later the eggs hatch and neonates begin tunneling at the innerbark-sapwood interface. Larvae leave this interface area the following season and tunnel into the sapwood and heartwood, 
where they eventually weaken the stems and predispose them to storm breakage. After feeding for 2 years in the South and up to 5 years in the North, larvae pupate inside the stem (133). Besides the damage done by the borer itself, woodpeckers exacerbate the problem, as they create even larger wounds while trying to find larvae. These wounds may become important infection courts for fungi, especially hypoxylon canker (107).

Nearly $20 \%$ of all $P$. deltoides in a clonal test were infested by S. calcarata (101). Higher infestation rates were observed in older cottonwoods as well as in some native $P$. deltoides clones represented in the study. Attacks occurring high on the stem can cause structural loss and increase susceptibility to wind breakage, especially following thinning. Management of $S$. calcarata is best done by maintaining dense, clean stands. Resistant cultivars have not yet been identified, but such selections could eventually be important in minimizing damage by this species. Highly infested trees should be removed from the stand and cut into small pieces, chipped, or burned to cause rapid desiccation and larval mortality.

The poplar branch borer, Oberea schaumii LeConte (Coleoptera: Cerambycidae), is one of several Oberea species that attack small-diameter Populus and Salix species in North America (133). O. schaumii preferentially attacks stems of young saplings and branches on trees and is most prevalent in low-density stands (99, 105). In mid to late June, females gnaw elongate, rectangular egg niches in the outer bark and insert eggs into the inner bark. Larvae bore downward $(15-30 \mathrm{~cm})$ from this point and eventually tunnel into the wood. They do not trigger an obvious swelling of the wood, and thus no gall develops. Their hidden tunneling and feeding are often revealed by either bleeding sap or golden sawdust-like frass emanating from the egg niche or 1 to 3 small shot holes in the stem 10 to $30 \mathrm{~cm}$ below the oviposition scar. It typically takes 1 to 2 years in the South and 3 to 4 years in the North to complete the life cycle. In young trees, the wounds can predispose trees to storm breakage or enhance hypoxylon canker infections (107).

Management of $O$. schaumii is best done by maintaining dense plantings on good sites. Stocking levels of less than 20,000 stems ha ${ }^{-1}$ are highly suitable for beetle infestation (99). Sanitation is recommended, along with employing resistant clones. Slowly growing trees on poor soils may be more susceptible because the trees' induced defenses, such as rapid callus formation and strong hypersensitive reactions to eggs and young larvae, may be debilitated. Fast-growing individuals may have more potent rapid inducible defenses that are effective against sedentary herbivores such as the small, young larvae of these beetles (59).

The cottonwood clearwing borer, Paranthrene dollii (Neumoegen) (Lepidoptera: Sesiidae), is of particular concern in cottonwood nursery operations in the southern United States. Adults are active from April through October, with peak flight between 1300 and $2000 \mathrm{~h}$ (100), and live for 10 to 18 days (36). Eggs are deposited singly on the bark, in the crevices and around wounds or scars (98). Oviposition sites usually are associated with the stool (i.e., a single stem that is cut, permitting multiple stems to regrow) in the nursery bed; however, they may also be found at various locations along the stem. Larvae bore into the stool, later move 
to the pith, and pupate at the end of the gallery. Early signs of attack are frass at the entrance hole and on the ground (22). First-year nursery plantings are not heavily attacked, but populations can build up in the rootstock in subsequent years. If the culled infested material is not properly disposed of and left on site, it serves as an infestation source the following year (T.E. Nebeker, personal observation). Infestations along the stem may weaken and break, causing a loss of potential cuttings that could be used in reforestation. The percentage of the rootstock infested increases yearly, necessitating the destruction of the rootstock. Damage in plantations is less evident, but some breakage can occur during the first and second growing seasons.

The cottonwood borer, Plectrodera scalator (F.) (Coleoptera: Cerambycidae), is distributed throughout the North American range of $P$. deltoides, but is of greatest concern in the South (130). Salix nigra and S. alba also are occasionally attacked. Adults emerge in early summer and begin feeding on petioles and tender bark (130). Oviposition occurs near the base of the tree; females dig a crude pit next to the root collar, chew through the bark, and lay a single egg (130). Larvae hatch and mine downward in the taproot and pupate the following spring. One- and two-year life cycles occur, but the mechanisms affecting voltinism are unknown (130).

Larval damage can increase tree susceptibility to wind or ice breakage and can seriously injure young trees (130). Adult feeding damage can be particularly bad; over $75 \%$ of one nursery had terminal damage and petiole breakage because of a $P$. scalator infestation (130). Chemical control is a viable management option, but timing must be precise to focus on adults. Few natural enemies are known for this pest.

\section{Salix: Willows}

DEFOLIATORS The imported willow leaf beetle, Plagiodera versicolora (Laicharting) (Coleoptera: Chrysomelidae), is the most economically important pest of intensively managed Salix in eastern North America, as high populations are capable of completely defoliating trees (145). Up to four generations per year are possible. Both adults and larvae feed on trees of the Salicaceae (primarily Salix and occasionally Populus) $(69,145)$. Approximately 3 weeks are required to reach the adult stage, after which an additional 3 to 4 weeks are spent feeding and reproducing (145). Several clutches of up to 20 eggs each are deposited on the underside of leaves. Adults preferentially feed and oviposit on younger leaves, on which larvae exhibit more rapid development compared to older leaves (72). Up to $45 \%$ clutch mortality can occur from larval cannibalism of unhatched eggs (145). Larvae forage gregariously during the first two instars and are solitary during the third instar and pupation.

Increased resource availability does not seem to contribute to increased $P$. versicolora larval performance (87). However, tree fertilization under flooded conditions increased adult $P$. versicolora feeding and oviposition (86). This suggests that adult $P$. versicolora choose trees with higher-quality foliage for feeding, which in turn encourages egg production. 
Nordman (106) tested 19 willow clones for resistance to $P$. versicolora. Leaf area consumption was consistent among clones, with only four showing significantly increased susceptibility over the other clones. However, selecting for resistant clones is still a potentially viable management option. Natural enemies remain the primary mechanism for $P$. versicolora management. Egg predators, including birds, hemipterans, and coccinellids, and egg and pupal parasitoids contribute to biological control of $P$. versicolora populations (145). Additional management tactics include the use of synthetic and biorational pesticides.

Both $N$. salicis-odoratus and $N$. ventralis Say are responsible for defoliating intensively managed willows in the northeastern United States (106). Warren (148) first reported the life history of $N$. salicis-odoratus on willow in Arkansas. The life history in the Pacific Northwest was similar, with the exception that the warmer temperatures and longer growing season in the South resulted in five instead of the three annual generations as reported in the Northwest (144).

There exists a wide range of clonal susceptibility to Nematus sawflies, especially among pure species and hybrid Salix eriocephala clones (106). Overall, N. ventralis consumed much more foliage than did $N$. salicis-odoratus (106). No discernable pattern arose on the basis of sawfly feeding preferences, thus breeding resistant Salix selections could prove challenging for this pest.

The willow shoot sawfly, Janus abbreviatus (Say) (Hymenoptera: Cephidae), is distributed over much of eastern North America. This insect is univoltine in the northern part of its range, whereas up to three generations per year can occur in the South. Ovipositing females girdle terminals (118) and larval tunneling causes stem mortality (134). There are few studies on this insect. Only minor damage was reported on a willow hybrid clone in New York (3); however, in some Asian willows and hybrids damage results in stem forking and reduced numbers of cuttings (L.P. Abrahamson, personal communication). In Mississippi, intensively managed $P$. deltoides were attacked primarily on side shoots, resulting in negligible damage, but Salix hybrids had greater numbers of attacks than a pure $S$. nigra clone (134). Over $90 \%$ of shoots were infested during the first generation in 1975 and 1976, while infestation rates dropped to less than $20 \%$ during the third generation (134).

Vigorous shoots are preferred for adult Nematus oviposition (17) and are positively correlated with increased larval performance (3). J. abbreviatus also preferred longer, more vigorous shoots for oviposition and development (134). Thus, the paradigm continues: Trees are bred for rapid growth rates (often sacrificing their inherent insect resistance) and planted in monocultures. These monocultures serve as prime locations for outbreak species such as $N$. salicis-odoratus, whose damage is exacerbated by a vigorous food source.

Generalist herbivores attacking willows in the Northeast include L. dispar and the Japanese beetle, Popillia japonica Newman (Coleoptera: Scarabaeidae), which have caused severe defoliation in certain willow clones (106), particularly in nurseries (L.P. Abrahamson, personal communication). The potato leafhopper, Empoasca fabae (Harris) (Hemiptera: Cicadellidae), has been so damaging to 
S. viminalis clones that they are no longer grown in E. fabae's natural range (L.P. Abrahamson, personal communication).

STEM BORERS The poplar-and-willow borer, Cryptorhynchus lapathi (L.) (Coleoptera: Curculionidae), is a robust weevil that attacks cottonwoods, poplars, willows, alders, and even birches $(11,12,69 \mathrm{a}, 133)$. This insect seems to prefer stems that are more than 2 years old and have a basal diameter greater than $25 \mathrm{~mm}$. It also may attack branches, as do S. inornata and O. schaumii. Adults emerge from infested stems during the late summer and early fall. After several days of feeding and mating, gravid females chew slits in the corky bark, often in lenticels, scar tissue, branch bases, and injured areas, typically within $40 \mathrm{~mm}$ from the root collar, and insert their eggs. The developing larvae feed at the innerbarksapwood interface and only later bore into the wood itself. The tree is weakened by the excavations and may break during wind, snow, or ice storms or die from stem girdling. Development from egg to sexually mature adult takes 1 to 2 years, but adults may overwinter (in the duff) and live up to 2 years. These carryover adults emerge as warm weather arrives the next spring and quickly begin ovipositing (43).

C. lapathi is capable of causing severe damage and mortality as has been seen in North American native willow stands, especially in British Columbia and Ontario $(11,12,133)$. This insect has been observed in commercial plantings in New York but has not yet caused noticeable damage (L.P. Abrahamson, personal communication). Management of $C$. lapathi is best done by maintaining well-stocked, thrifty stands. Variations in susceptibility among cultivars of poplar have been observed but not widely tested across environments $(69 a, 126)$. Planting young trees near older trees that may be infested is not recommended. Resistant clones would be highly desirable if they were available. Complete removal and chipping or burning of infested trees is recommended.

\section{Liquidambar: Sweetgum}

Sweetgum is planted primarily in the southeastern United States and is an attractive species for intensive management because of its high vigor, rapid growth rate, and general resistance to most pests. Generalist folivores may pose a threat to intensively managed sweetgum, especially those receiving increased silvicultural amendments such as fertilization. A recent study (147) found significantly higher damage ratings and seedling mortality on fertilized trees. Seedling mortality was caused by the yellowstriped armyworm, Spodoptera ornithogalli (Gueneé) (Lepidoptera: Noctuidae), a previously undocumented pest on sweetgum (147).

Southern $M$. disstria populations reared on sweetgum have fecundity rates that are nearly twice that of northern populations (109). Significant differences in larval $M$. disstria preference and performance occurred among 16 greenhouse-grown and 16 field-grown sweetgum families (68). Up to 10-fold differences in leaf area consumed existed among sweetgum cultivars, which suggests that selective breeding for resistance may be an effective pest management approach. Alternatively, pesticides may be used to control arthropod pests if defoliation levels approach 
economically damaging levels. However, sweetgum is quite tolerant to artificial (and presumably natural) defoliation. Recent work conducted to simulate natural defoliator outbreaks showed that stem height and diameter were reduced initially after a single intense artificial defoliation event (67\% or $99 \%$ of crown removed), but recovered by 30 months post-defoliation (68). However, after a second intensive defoliation event the following year, diameter growth had not recovered 18 months later. Furthermore, interactions between defoliation and other stress factors can alter response patterns in seedlings (10). Studies that include multiple variables are particularly important because they closely replicate conditions encountered in the field.

L. dispar is an exotic folivore responsible for the defoliation of millions of acres of hardwood forest in the northeastern and midwestern United States. L. dispar performed better on sweetgum compared with other tree species in the Southeast (6, 129). Of five hardwoods evaluated, larval L. dispar reared on sweetgum exhibited the second-lowest mortality, highest pupal weight, shortest larval developmental time, and highest adult fecundity (6). Two recent studies $(141,142)$ supported the finding that sweetgum is a nutritionally acceptable host for $L$. dispar development. Of seven tree species evaluated, only red oak foliage was comparable to sweetgum with respect to fifth instar preference and consumption (129). While the potential exists for $L$. dispar to impact sweetgum plantations, to our knowledge, there have been no such studies.

\section{Platanus: American Sycamore}

American sycamore grows across much of the eastern United States and is valued as a timber source in the South. The greatest threat to intensively managed sycamore comes from disease; however, several insect species also are problematic and can exhibit localized outbreaks. One folivore capable of inflicting substantial damage is the sycamore leaf beetle, Neochlamisus platani (Brown) (Coleoptera: Chrysomelidae) $(64,79)$. Upon hatching in the spring, larvae construct protective cases using their own frass, so they are also called case-bearing leaf beetles (79). Larvae are voracious feeders, usually consuming only young foliage; however, older foliage may also be consumed when large populations are present. Natural enemies generally control $N$. platani populations, and beetle damage is most often aesthetic. However, occasional outbreaks may require chemical treatment.

With a life cycle of around 30 days, the sycamore lace bug, Corythucha ciliata (Say) (Hemiptera: Tingidae), can have more than five generations per year in the southern United States (79). Both adults and larvae feed on the underside of leaves. During dry weather or heavy infestations, $C$. ciliata feeding can result in premature leaf abscission $(35,79)$, possibly requiring chemical control. A single leaf can have over 1000 C. ciliata eggs; estimates of egg densities greater than 2 per $\mathrm{cm}^{2}$ of leaf area result in a heavily infested tree, possibly requiring additional treatment (63). However, C. ciliata eggs and neonates are prone to high mortality rates from various natural enemies $(61,62)$ including lacewings, thrips, and predatory hemipterans. 
Eight Erythroneura leafhopper species coexist on sycamore leaves (93, 94). One species, E. lawsoni Robinson (Hemiptera: Cicadellidae), was abundant in a sycamore plantation in South Carolina during the 2000-2003 growing seasons (D.R. Coyle, personal observation). These insects overwinter in leaf litter and begin feeding concurrently with the spring leaf flush (92). Leafhopper feeding stipples leaves, particularly in the lower canopy (94), decreasing their photosynthetic capacity. Increased E. lawsoni populations and oviposition rates were found on trees receiving fertilization and irrigation amendments, which suggests that these cultural treatments, commonly applied to plantation hardwoods in the South, could increase a plantation's susceptibility to certain pests (D.R. Coyle \& J. Bentz, unpublished data).

N. platani, C. ciliata, and E. lawsoni would not require additional cultural controls under traditional forest conditions. However, IMHFS can create the right suite of characteristics to increase the potential for and effects of pest outbreaks. In these cases, chemical control may be required for these pests.

\section{DESIGNING INTENSIVELY MANAGED HARDWOOD ECOSYSTEMS TO DECREASE PEST SUSCEPTIBILITY}

Unless one purposely designs IMHFS to minimize the probability of economic damage from potential pest populations, the opposite is likely to happen (135). A prime example of effective plantation design is the Willow Biomass Program in New York. Willow selections (5-8 per plantation) are planted in row-blocks, intermixing selections that are susceptible to pests with those that are resistant. There is a risk that pushing plant growth with silvicultural amendments, such as irrigation and fertilizers, to the limits of plant carbon resources may compromise defenses and furthermore increase tissue quality for insect growth, reproduction, and survival $(44,53,57,58,60,75)$. Pest management concerns must be integrated into the entire program of plantation establishment and culture $(28,120,136)$ to prevent problems that scientists will otherwise be forced to solve.

There are several guiding principles to consider. First, resistant plant cultivars should be employed whenever possible. Unfortunately, there is not enough detailed knowledge about host plant resistance to insects in these developing systems for species or cultivar selections to have a significant impact. There is no dispute that there are substantial variations in the natural resistance of the trees in question (41, $54,57,89,122,123)$, but to develop these resistance traits to the point of economic utility requires long-term research. Hybrids between closely related species, such as oaks (Quercus spp.), poplars, spruces (Picea spp.), willows, and others, should be regarded skeptically and tested rigorously because of the increased probabilities of hybrid defensive dysfunction and the possibilities of sharing specialist herbivores from both parental lineages $(41,91)$.

Second, it is advisable to avoid monocultures and instead employ polycultures or mixed species plantings, especially plants that have different mechanisms of 
resistance to the main pests $(28,81,119,120,155)$. Three or more significantly different cultivars would be preferable to fewer when designing a polyculture, so as to minimize the evolutionary capacity of pests to adapt to the defenses of the host plants $(42,45,115)$. In addition, one would like to exploit associational resistance, i.e., in which one or more plant species or cultivar somehow interferes with the normal host finding, survival, and growth of the herbivores on the associated plant species or cultivar (49). However, there is always the danger that associational susceptibility rather than resistance may occur (149). This is an unintended extension of the underlying problems of increasing the abundance of the primary crop plant(s).

Third, one should create landscape checkerboard mosaics of smaller plantations rather than fewer larger plantations $(28,155)$. Defining "small" is difficult because optimal size depends to a great degree on the vagility of the primary pest species. Likewise, there are innumerable practical constraints on the ad hoc definition, determined by economics and logistics. However, all the variables must be considered. Small plantations with a higher proportion of edge should be protected by rows of different plant species that are unlikely to share insects with the crop tree species (i.e., border plants should exhibit associational neutrality or resistance). For example, many species of sawflies and wood borers prefer warmer, higher-light environments for oviposition and therefore edges are more vulnerable to injury. In keeping plantations small, the objective is to isolate each plantation as much as possible from the metapopulations of pest insects. This means, of course, that crop plantations should be isolated from one another and especially from the forests of similar species to hold down the immigration of pests derived from their natural reservoirs. Small plantations support smaller pest populations that may have higher probabilities of death from natural enemies and stochastic extinctions (15). Ample evidence suggests that making a relatively scarce plant more abundant inevitably increases its potential for pest population outbreaks (47).

Fourth, it is advisable to maintain the ratio of natural enemy to pest as high as possible. This requires facilitating the populations and the efficacies of natural enemies within and near each plantation. This could entail establishing IMHFS near neutral sources of natural enemies, such as ecosystems composed of distantly related plants that support nonthreatening herbivores that have generalist enemies that would spill into the crop plantations. Bird, small mammal, and invertebrate predators might be encouraged by judicious use of artificial shelters and/or coarse woody debris. Increasing the longevity and the efficacy of parasitoid populations might be accomplished by planting special-nectar-yielding herbs and shrubs or facilitating honeydew-secreting scales and aphids (16).

The future success of IMHFS, like that of any crop system, depends on adaptive management, i.e., learning from experience and making appropriate tactical and strategic adjustments. This is especially true for IMHFS because we have much to learn with respect to ecologically sound and cost-effective IPM strategies. Studies that simultaneously examine multiple stressors or pests $(10,73,106,124,143)$ are particularly valuable, as these types of studies more closely mimic what actually 
occurs in natural situations. Moreover, it is probably unrealistic to expect that there will ever be invariant, long-term solutions to particular problem pests because these pests are always evolving and new challenges are always arising (e.g., consider the continual onslaughts of exotic insects). In addition, the external economic and environmental conditions are changing especially fast owing to globalization of markets, burgeoning population pressures, rapid technological advances, everrising costs of fossil fuels, alternative nonwoody fiber sources, and potentially significant global climate changes that may generate more unpredictable weather for growing crops. However, IMHFS are particularly adaptable wood cropping systems that may meet the unique challenges of our times because crop cultivars, species, stands, and landscapes can be changed frequently owing to the particularly fast growth and short-rotation times of the crop trees.

\section{ACKNOWLEDGMENTS}

The authors thank Dan Robison (North Carolina State University) and Larry Abrahamson (Syracuse University) for their insightful comments on an earlier version of this manuscript. Partial Funding for D.R.C. was provided by the Department of Energy-Savannah River Operations office through the Forest Service Savannah River and the Forest Service Southern Research Station under Interagency Agreement DE-IA09-00SR22188. Partial funding for T.E.N. was provided in part through the Mississippi Agriculture and Forestry Experiment Station, USDA Forest Service Cooperative Grant No. 19-92-039. This paper is approved for publication as Journal Article No. BC-10521 of the Mississippi Agricultural and Forestry Experiment Station, Mississippi State University.

\section{The Annual Review of Entomology is online at http://ento.annualreviews.org}

\section{LITERATURE CITED}

1. Abrahamson LP, Morris RC, Overgaard NA. 1977. Control of certain insect pests in cottonwood nurseries with the systemic insecticide carbofuran. J. Econ. Entomol. 70:89-91

2. Abrahamson LP, Robison DJ, Volk TA, White EH, Neuhauser EF, et al. 1998. Sustainability and environmental issues associated with willow bioenergy development in New York (U.S.A.). Biomass Bioenergy 15:17-22

3. Abrahamson LP, Robison DJ, Volk TA, White EH, Nordman E, Kopp R. 2001. Native willow collection and insect resistant evaluation of willow and hybrid- poplar production clones. Final Rep. Electric Power Res. Inst. US Dep. Energy

4. Augustin S, Wagner MR, Clancy KM. 1994. Chrysomela scripta performance on five poplar clones. Norw. J. Agric. Sci. Suppl. 18:111-17

5. Baker EW, Kono T, Amrine JW Jr, Delfinado-Baker M, Stasny TA. 1996. Eriophyid Mites of the US. West Bloomfield, MI: Indira Publ. House

6. Barbosa P, Waldvogel M, Martinat P, Douglas LW. 1983. Developmental and reproductive performance of the gypsy moth, Lymantria dispar (L.) 
(Lepidoptera: Lymantriidae), on selected hosts common to Mid-Atlantic and Southern forests. Environ. Entomol. 12:1858-62

7. Bauer LS, Pankratz HS. 1993. Nosema scripta N. Sp. (Microsporidia: Nosematidae), a microsporidian parasite of the cottonwood leaf beetle Chrysomela scripta (Coleoptera: Chrysomelidae). J. Eukaryot. Microbiol. 40:135-41

7a. Bergmann BA. 2003. Five years of Paulownia field trials in North Carolina. NewFor. 25:185-99

8. Bingaman BR, Hart ER. 1992. Feeding and oviposition preferences of adult cottonwood leaf beetles (Coleoptera: Chrysomelidae) among Populus clones and leaf age classes. Environ. Entomol. 21:508-17

9. Bingaman BR, Hart ER. 1993. Clonal and leaf age variation in Populus phenolic glycosides: implications for host selection by Chrysomela scripta (Coleoptera: Chrysomelidae). Environ. Entomol. 22:397-403

10. Birks P, Robison D. 1999. Screening sweetgum seedling families for growth and stress response. Proc. 25th Bienn. South. For. Tree Improv. Conf., 11-14 July, New Orleans, LA, pp. 36-39

10a. Bohanek JR, Groninger JW. 2002. Impacts of intensive management on black walnut (Juglans nigra L.) growth and bole quality at mid-rotation. For. Sci. 49:522-29

11. Broberg CL, Borden JH, Humble LM. 2001. Host range, attack dynamics, and impact of Cryptorhynchus lapathi (Coleoptera: Curculionidae) on Salix (Salicaceae) spp. Can. Entomol. 133: 119-30

12. Broberg CL, Borden JH, Humble LM. 2002. Distribution and abundance of Cryptorhynchus lapathi on Salix spp. in British Columbia. Can. J. For. Res. 32:561-68

13. Brown WJ. 1956. The new world species of Chrysomela L. (Coleoptera:
Chrysomelidae). Can. Entomol. 88:5-54

14. Caldbeck ES, McNabb HS Jr, Hart ER. 1978. Poplar clonal preferences of the cottonwood leaf beetle. J. Econ. Entomol. 71:518-20

15. Cappuccino N, Lavertu D, Bergeron Y, Reniere J. 1998. Spruce budworm impact, abundance and parasitism rate in a patchy landscape. Oecologia 114:23642

16. Cappuccino N, Marie-José H, Stein J. 1999. The influence of understory nectar resources on parasitism of the spruce budworm Choristoneura fumiferana in the field. Agric. For. Entomol. 1:3336

17. Carr TG, Roininen H, Price PW. 1998. Oviposition preference and larval performance of Nematus oligospilus (Hymenoptera: Tenthredinidae) in relation to host plant vigor. Environ. Entomol. 27:615-25

18. Cerezke HF, Volney WJ. 1995. Forest insect pests in the Northwest Region. In Forest Insect Pests in Canada, ed. JA Armstrong, WG Ives, pp. 59-72. Ottawa: Can. For. Serv. Sci. Sustain. Dev. Dir. $732 \mathrm{pp}$.

19. Ceulemans R, Deraedt W. 1999. Production physiology and growth potential of poplars under short-rotation forestry culture. For. Ecol. Manag. 121:9-23

20. Chapin FS III, Autumn K, Pugnaire F. 1993. Evolution of suites of traits in response to environmental stress. Am. Nat. 142:S78-92

21. Chastagner GA, Hudak JM. 1999. Crop profile for hybrid poplars in Washington and Oregon. Wash. State Univ. Coop. Ext. Publ. No. MISC0355E. 12 pp.

22. Cook JR, Solomon JD. 1976. Damage, biology and natural control of insect borers in cottonwood (Populus deltoids Bartr.). Proc. Symp. East. Cottonwood Relat. Species, 28 Sept. 2 Oct., Greenville, MS, pp. 272-76. Baton Rouge: La. State Univ., Div. Contin. Educ. 
23. Coster JE, Merrifield RG, Woessner RA. 1972. Evaluation of four systemic insecticides against the cottonwood twig borer. J. Econ. Entomol. 65:61213

24. Coyle DR. 2002. Effects of clone, silvicultural, and miticide treatments on cottonwood leafcurl mite (Acari: Eriophyidae) damage in plantation Populus. Environ. Entomol. 31:1000-8

25. Coyle DR, Amrine JW Jr. 2004. New collection records and host range of the cottonwood leafcurl mite, Tetra lobulifera (Keifer) (Acari: Eriophyidae), in the USA. Int. J. Acarol. 30:3-8

26. Coyle DR, McMillin JD, Hall RB, Hart ER. 2001. Cottonwood leaf beetle (Coleoptera: Chrysomelidae) larval performance on eight Populus clones. Environ. Entomol. 30:748-56

27. Coyle DR, McMillin JD, Hall RB, Hart ER. 2002. Cottonwood leaf beetle (Coleoptera: Chrysomelidae) defoliation impact on Populus growth and aboveground volume in a short-rotation woody crop plantation. Agric. For. Entomol. 4:293-300

28. Coyle DR, McMillin JD, Hall RB, Hart ER. 2002. Deployment of tree resistance to insects in short-rotation Populus plantations. In Mechanisms and Deployment of Resistance in Trees to Insects, ed. MR Wagner, KM Clancy, F Lieutier, TD Paine, pp. 189-215. New York: Kluwer Acad.

29. Coyle DR, McMillin JD, Hall RB, Hart ER. 2003. Effects of cottonwood leaf beetle (Coleoptera: Chrysomelidae) larval defoliation, clone, and season on Populus foliar phagostimulants. Environ. Entomol. 32:452-62

30. Coyle DR, McMillin JD, Hart ER. 1999. Pupal and adult parameters as potential indicators of cottonwood leaf beetle (Coleoptera: Chrysomelidae) fecundity and longevity. Great Lakes Entomol. 32:107-13

31. Coyle DR, McMillin JD, Krause SC,
Hart ER. 2000. Laboratory and field evaluations of two Bacillus thuringiensis formulations, Novodor and Raven, for control of the cottonwood leaf beetle (Coleoptera: Chrysomelidae). J. Econ. Entomol. 93:713-20

32. Dahlsten DL, Rowney DL, Robb KL, Shaw DA, Kabashima JN. 2003. Biological control of introduced psyllids on Eucalyptus. Proc. 1st Int. Symp. Biol. Control Arthropods. USDA For. Serv. FHTET-03-05:356-61

33. Dickmann DI. 2001. An overview of the genus Populus. See Ref. 33a, pp. 1-42

33a. Dickmann DI, Isebrands JG, Eckenwalder JE, Richardson J, eds. 2001. Poplar Culture in North America. Ottawa, Can.: NRC Res. Press

34. Dickmann DI, Stuart KW. 1983. The Culture of Poplars in Eastern North America. East Lansing: Mich. State Univ. Press

35. Drooz AT. 1985. Insects of Eastern Forests. Misc. Publ. 1426. Washington, DC: USDA For. Serv. 608 pp.

36. Eroles-Harkins L. 1983. Biology and life history of the cottonwood clearwing borer, Paranthrene dollii (Neum.) (Lepidoptera: Sesiidae), in the laboratory and a cottonwood nursery in Mississippi. MS thesis. Miss. State Univ. 106 pp.

37. Fang Y, Hart ER. 2000. Effect of cottonwood leaf beetle (Coleoptera: Chrysomelidae) larval population levels on Populus terminal damage. Environ. Entomol. 29:43-48

38. Fang Y, Pedigo LP, Colletti JP, Hart ER. 2002. Economic injury level for second-generation cottonwood leaf beetle (Coleoptera: Chrysomelidae) in twoyear-old Populus. J. Econ. Entomol. 95:313-16

39. Fitzgerald TD. 1995. The Tent Caterpillars. London: Cornell Univ. Press

40. Frederici BA, Bauer LS. 1998. Cyt1Aa protein of Bacillus thuringiensis is toxic to the cottonwood leaf beetle, Chrysomela scripta, and suppresses high 
levels of resistance to Cry3Aa. Appl. Environ. Microbiol. 64:4368-71

41. Fritz RS, Moulia C, Newcombe G. 1999. Resistance of hybrid plants and animals to herbivores, pathogens, and parasites. Annu. Rev. Ecol. Syst. 30:565-91

42. Fritz RS, Simms EL, eds. 1992. Plant Resistance to Herbivores and Pathogens: Ecology, Evolution, and Genetics. Chicago: Univ. Chicago Press

43. Furniss MM. 1972. Poplar-and-willow borer. For. Pest Leafl. 121, USDA For. Serv. 5 pp.

44. Glynn C, Herms DA, Egawa M, Hansen R, Mattson WJ. 2003. Effects of nutrient availabilty on biomass allocation as well as consititutive and induced resistance in poplar. Oikos 101:385-97

45. Gould F. 1991. The evolutionary potential of crop pests. Am. Sci. 79:496-507

46. Grigarick AA, Lange WH. 1968. Seasonal development and emergence of two species of gall-forming aphids, Pemphigus bursaris and $P$. nortoni, associated with poplar trees in California. Ann. Entomol. Soc. Am. 61:509-14

47. Haack RA, Mattson WJ. 1993. Life history patterns of North American treefeeding sawflies. In Sawfly Life History Adaptations to Woody Plants, ed. MR Wagner, KF Raffa, pp. 503-45. New York: Academic

48. Hall RB, Miller GA, Robison TL, Onokpise OU. 1983. Developing Alnus for use in intensive culture. In Intensive Plantation Culture: 12 Years Research, ed. EA Hansen, pp. 35-45. USDA For. Serv. Gen. Tech. Rep. NC-91. 154 pp.

49. Hämback PA, Agren J, Ericson L. 2000. Associational resistance: insect damage to purple loosestrife reduced in thickets of sweet gale. Ecology 81:178494

49a. Hanover JW. 1993. Black locust: an excellent fiber crop. In New Crops, ed. J Janik, JE Simon, pp. 432-35. New York: Wiley

50. Harrell MO, Benjamin DM, Berbee JG,
Burkot TR. 1981. Evaluation of adult cottonwood leaf beetle, Chrysomela scripta (Coleoptera: Chrysomelidae), feeding preference for hybrid poplars. Great Lakes Entomol. 14:181-84

51. Hart ER, Hall RB, Hanna RD. 1991. Dispersal of Fenusa dohrnii (Hymenoptera: Tenthredinidae) from an Alnus shortrotation forest plantation. Great Lakes Entomol. 24:63-68

52. Haugen DA. 1985. Oviposition preference of the cottonwood leaf beetle, Chrysomela scripta $F$., on poplar clones, Populus spp. PhD thesis. Iowa State Univ., Ames. 66 pp.

53. Haukioja E. 2003. Putting the insect into the birch-insect interaction. Oecologia 136:161-68

54. Havill NP, Raffa KF. 1999. Effects of elicitation treatment and genotypic variation on induced resistance in Populus: impacts on gypsy moth (Lepidoptera: Lymantriidae) development and feeding behavior. Oecologia 120:295-303

55. Head R, Neel WW, Sartor CF, Chambers H. 1977. Methyl parathion and carbaryl resistance in Chrysomela scripta and Coleomegilla maculata. Bull. Environ. Contam. Toxicol. 17:163-64

56. Head RB, Neel WW. 1973. The cottonwood leaf beetle: observations on the biology and reproductive potential in Mississippi. J. Econ. Entomol. 66:132728

57. Herms DA. 2002. Strategies for deployment of insect resistant ornamental plants. In Mechanisms and Deployment of Resistance in Trees to Insects, ed. MR Wagner, KM Clancy, F Lieutier, TD Paine, pp. 217-37. New York: Kluwer Acad.

58. Herms DA. 2002. Effects of fertilization on insect resistance of woody ornamental plants: reassessing an entrenched paradigm. Environ. Entomol. 31:923-33

59. Herms DA, Mattson WJ. 1992. The dilemma of plants: to grow or defend? Q. Rev. Biol. 67:283-335 
60. Herms DA, Mattson WJ. 1997. Trees, stress, and pests. In Plant Health Care for Woody Ornamentals, pp. 13-25. UrbanaChampaign: Univ. Ill. Coop. Ext. Serv. $223 \mathrm{pp}$.

61. Horn KF, Farrier MH, Wright CG. 1983. Estimating egg and first-instar mortalities of the sycamore lace bug, Corythuca ciliata (Say). J. Ga. Entomol.Soc. 18:2737

62. Horn KF, Farrier MH, Wright CG. 1983. Some mortality factors affecting eggs of the sycamore lace bug, Corythuca ciliata (Say) (Hemiptera: Tingidae). Ann. Entomol. Soc. Am. 76:262-65

63. Horn KF, Farrier MH, Wright CG, Nelson LA. 1983. A sampling method for estimating egg and first-instar densities of the sycamore lace bug, Corythuca ciliata (Say). J. Ga. Entomol. Soc. 18:37-49

64. Hyche LL. 1996. The sycamore leaf beetle: a guide to recognition and habits in Alabama. Ala. Agric. Exp. Stn. Bull. 630. $11 \mathrm{pp}$.

65. Ives WGH, Wong HR. 1988. Tree and shrub insects of the prairie provinces. Can. For. Serv. North For. Cent. Edmonton, Alberta, NOR-X-292. 327 pp.

66. James RR, Croft BA, Strauss SH. 1999. Susceptibility of the cottonwood leaf beetle (Coleoptera: Chrysomelidae) to different strains and transgenic toxins of Bacillus thuringiensis. Environ. Entomol. 28:108-15

67. Jarrard JA. 1997. Natural enemies of the cottonwood leaf beetle in central Iowa. MS thesis. Iowa State Univ., Ames. 118 pp.

68. Jetton RM. 2002. Defoliation tolerance and resistance to the forest tent caterpillar, Malacasoma disstria Hbn., in sweetgum, Liquidambar styraciflua $L$. MS thesis. N.C. State Univ., Raleigh. 119 pp.

69. Jones DC, Coleman JS. 1988. Plant stress and insect behavior: cottonwood, ozone, and the feeding and oviposition preference of a beetle. Oecologia 76:5156 69a. Johnson JD, Johnson KR. 2003. Hybrid poplar genotype affects attack incidence by the poplar-and-willow borer (Cryptorhynchus lapathi). West. J. Appl. For. 18:276-80

70. Jones TH, Gillette CP. 1918. Life history of Pemphigus populitransversus. J. Agric. Res. 13:577-94

71. Kang H, Hall RB, Heuchelin SA, McNabb HS Jr, Mize CW, Hart ER. 1997. Transgenic Populus: in vitro screening for resistance to cottonwood leaf beetle (Coleoptera: Chrysomelidae). Can. J. For. Res. 27:943-44

72. King BH, Crowe ML, Blackmore MD. 1998. Effects of leaf age on oviposition and on offspring fitness in the imported willow leaf beetle Plagiodera versicolora (Coleoptera: Chrysomelidae). J. Insect. Behav. 11:23-36

73. Klepzig KD, Robison DJ, Smalley EB, Raffa KF. 1997. Effects of feeding by two folivorous arthropods on susceptibility of hybrid poplar clones to a foliar pathogen. Great Lakes Entomol. 30:99104

74. Klopfenstein NB, McNabb HS Jr, Hart ER, Hall RB, Hanna RD, et al. 1993. Transformation of Populus hybrids to study and improve pest resistance. Silvae Genet. 42:86-90

75. Kytö M, Niemelä P, Larsson S. 1996. Insects on trees: populations and individual responses to fertilization. Oikos 75:14859

76. Labrecque M, Teodorescu TI. 2003. High biomass yield achieved by Salix clones in SRIC following two 3year coppice rotations on abandoned farmland in southern Quebec, Canada.

Biomass Bioenergy 25:135-46

77. Land SB Jr, Ezell AW, Schoenholtz SH, Tuskan GA, Tschaplinski TJ, et al. 1996. Intensive culture of cottonwood and hybrid poplars. Proc. 35th LSU For. Symp. Baton Rouge, LA, pp. 167-89

78. Leather SR. 1986. Insect species richness of the British Rosaceae: the importance 
of host range, plant architecture, age of establishment, taxonomic isolation and species area relationships. J. Anim. Ecol. 55:841-60

79. Leininger TD, Solomon JD, Wilson AD, Schiff NM. 1999. A guide to major insects, diseases, air pollution injury, and chemical injury of sycamore. Gen. Tech. Rep. SRS-28, USDA For. Serv., South. Res. Stn., Asheville, NC. 44 pp.

80. Leplé JC, Bonadé-Bottino $\mathrm{M}, \mathrm{Au}-$ gustin S, Pilate G, Lê Tân VD, et al. 1995. Toxicity to Chrysomela tremulae (Coleoptera: Chrysomelidae) of transgenic poplars expressing a cysteine proteinase inhibitor. Mol. Breed. 1:319-28

81. Libby WJ, Cockerham CC. 1980. Random non-contiguous plots in interlocking field layouts. Silvae Genet. 29:18390

82. Lin S, Binder BF, Hart ER. 1998. Insect feeding stimulants from the leaf surface of Populus. J. Chem. Ecol. 24:1781-90

83. Lin S, Binder BF, Hart ER. 1998. Chemical ecology of cottonwood leaf beetle adult feeding preferences on Populus. J. Chem. Ecol. 24:1791-802

84. Lindroth RL, Bloomer MS. 1991. Biochemical ecology of the forest tent caterpillar: responses to dietary protein and phenolic glycosides. Oecologia 86:40813

84a. Lindroth RL, Hwang S-Y. 1996. Diversity, redundancy, and multiplicity in chemical defense systems of aspen. In Phytochemical Diversity and Redundancy in Ecological Interactions, ed. JT Romeo, JA Saunders, P Barbosa, pp. 2556. New York: Plenum.

85. Loehle C, Namkoong G. 1987. Constraints on tree breeding: growth tradeoffs, growth strategies, and defensive investments. For. Sci. 33:1089-97

86. Lower SS, Kirshenbaum S, Orians CM. 2003. Preference and performance of a willow-feeding beetle: soil nutrient and flooding effects on host quality. Oecologia 136:402-11
87. Lower SS, Orians CM. 2003. Soil nutrients and water availability interact to influence willow growth and chemistry but not leaf beetle performance. Entomol. Exp. Appl. 107:69-79

88. Mattson WJ. 1980. Herbivory in relation to plant nitrogen content. Annu. Rev. Ecol. Syst. 11:119-61

89. Mattson WJ, Hart ER, Volney WJA. 2001. Insect pests of Populus: coping with the inevitable. See Ref. 33a, pp. 219-48

90. Mattson WJ, Herms DA, Witter JA, Allen DC. 1991. Woody plant grazing systems: North American outbreak folivores and their host plants. In Forest Insect Guilds: Patterns of Interaction With Host Trees, ed. YN Baranchikov, WJ Mattson, F Hain, TL Payne, pp. 5378. USDA For. Serv. GTR NE-153. 400 $\mathrm{pp}$.

91. Mattson WJ, Lawrence RK, Birr BA. 1996. $F_{1}$ hybrid spruces inherit the phytophagous insects of their parents. In $D y$ namics of Forest Herbivory: Quest for Pattern and Principle, ed. WJ Mattson, P Niemela, M Rousi, pp. 142-49. USDA For. Serv. Gen. Tech. Rep. NC-183. 286 pp.

92. McClure MS. 1974. Biology of Erythroneura lawsoni (Homoptera: Cicadellidae) and coexistence in the sycamore leaf-feeding guild. Environ. Entomol. 3:59-68

93. McClure MS. 1975. Key to the eight species of Erythroneura leafhoppers (Homoptera: Cicadellidae) on American sycamore. Ann. Entomol. Soc. Am. 68: 1039-43

94. McClure MS, Price PW. 1975. Competition among sympatric Erythroneura leafhoppers (Homoptera: Cicadellidae) on American sycamore. Ecology 56:1388-97

95. McCown BH, McCabe DE, Russell DR, Robison DJ, Barton KW, Raffa KF. 1991. Stable transformation of Populus and incorporation of pest resistance by 
electric discharge particle acceleration. Plant Cell Rep. 9:590-94

96. McMillin JD, Anderson MJ, Butin EE, Hart ER. 1998. Phenology and infestation patterns of the cottonwood twig borer (Lepidoptera: Tortricidae) in Iowa. Great Lakes Entomol. 31:181-90

97. Morris RC. 1967. Biology of Gypsonoma hiambachiana (Lepidoptera: Olethreuidae), a twig borer in eastern cottonwood. Ann. Entomol. Soc. Am. 60: 423-27

98. Morris RC, Filer TH, Solomon JD, McCracker FI, Overgard NA, Weiss MJ. 1975. Insects and diseases of cottonwood. Gen. Tech. Rep. SO-8. USDA For. Serv., South. For. Exp. Stn. 37 pp.

99. Myers WL, Knight FB, Grimble DG. 1968. Frequency of borer attacks as related to character of aspen sucker stands: a comparative study of Oberea schaumii and Saperda inornata. Ann. Entomol. Soc. Am. 61:1418-23

100. Nebeker TE, Eroles-Harkins L, Solomon JD, Doolittle RE. 1988. Daily and seasonal flight of male Paranthrene dolli (Lepidoptera: Sesiidae), monitored by pheromone traps. Fla. Entomol. 71: 376-80

101. Nebeker TE, Schmitt JJ, Solomon JD, Honea CR. 1985. Clonal resistance to and incidence of the poplar borer in southern cottonwood plantations. Proc. 3rd Bienn. South. Silvic. Res. Conf., 7-9 Nov. 1984, Atlanta, GA. USDA For. Serv. So. For. Exp. Stn. Gen. Tech. Rep. SO54 , pp. 247-51

101a. Nebeker TE, Warriner MD, Hart ER. 2001. Cottonwood leaf beetle in fiber farms: predicting emergence and development and insect-plant interactions: new associations - aphids and Populus roots. Poster Pres. South. For. Ins. Work Conf., 23-26 July 2001, Jeckyll Island, $G A$

102. Nebeker TE, Warriner MD, Hart ER. 2002. Cottonwood fiber farm pest management: cottonwood leaf beetle. In
Proc. 11th Bienn. South. Silvic. Res. Conf., Gen. Tech. Rep. SRS-48, ed. KW Outcalt, pp. 565-68. Asheville, NC: USDA For. Serv., South. Res. Stn. 622 pp.

103. Newcombe G. 1996. The specificity of fungal pathogens to Populus. In Biology of Populus and Its Implications for Management and Conservation, ed. RF Stettler, HD Bradshaw, PE Heilman, TM Hinckley, pp. 223-46. Ottowa, Can.: NRC Res. Press

104. Niemela P, Neuvonen S. 1983. Species richness of herbivores on hosts-how robust are patterns revealed by analyzing published host plant lists. Ann. Entomol. Fenn. 49:95-99

105. Nord JC, Grimble DG, Knight FB. 1972. Biology of Oberea schaumii (Coleoptera: Cerambycidae) in trembling aspen, Populus tremuloides. Ann. Entomol. Soc. Am. 65:114-19

106. Nordman EE. 1998. Evaluation of willow and poplar biomass production clones for resistance to multiple insect pests. MS thesis. State Univ. NY, Syracuse. 110 pp.

107. Ostry ME, Wilson LF, McNabb HS, Moore LM. 1989. A guide to insect, disease, and animal pests of poplar. USDA Agric. Handb. 677. 118 pp.

108. Paine TD, Millar JG. 2003. Biological control of introduced pests of Eucalyptus in California. Proc. 1st Int. Symp. Biol. Control Arthropods. USDA For. Serv. FHTET-0305, pp. 66-71

109. Parry D, Goyer RA, Lenhard GJ. 2001. Macrogeographic clines in fecundity, reproductive allocation, and offspring size of the forest tent caterpillar Malacosoma disstria. Ecol. Entomol. 26:28191

110. Parry D, Spence JR, Volney WJA. 1997. The response of natural enemies to experimentally increased populations of forest tent caterpillar. Ecol. Entomol. 22: 97-108

111. Parry D, Spence JR, Volney WJA. 
1998. Budbreak phenology and natural enemies mediate survival of early instar forest tent caterpillar (Lepidoptera: Lasiocampidae). Environ. Entomol. 27: 1368-74

112. Payne TL, Woessner RA, Mastro VC. 1972. Evaluation of cottonwood clonal selections for resistance to cottonwood twig borer attack. J. Econ. Entomol. 65:1178-79

113. Peterson EB, Peterson NM, McLennan DS. 1996. Black cottonwood and balsam poplar managers' handbook for British Columbia. FRDA Rep. 250. For. Can. Br. Columbia Minist. For. 116 pp.

114. Prentice RM. 1963. Forest Lepidoptera of Canada. Vol. 3: Lasiocampidae, Drepanidae, Thyatiridae, Geometridae. Can. Dep. For. Publ. 1013, pp. 282543

115. Raffa KF. 1989. Genetic engineering of trees to enhance resistance to insects: evaluating the risks of biotype evolution and secondary pest outbreak. BioScience 39:524-34

116. Reichenbacker RR, Schultz RC, Hart ER. 1996. Impact of artificial defoliation on Populus growth, biomass production, and total non-structural carbohydrate concentration. Environ. Entomol. 25:632-42

117. Riemenschneider DE, Berguson WE, Dickmann DI, Hall RB, Isebrands JG, et al. 2001. Poplar breeding and testing strategies in the north-central US: demonstration of potential yield and consideration of future research needs. For. Chron. 77:245-53

118. Riley CV. 1888. The willow shoot sawfly. Insect Life 1:8-11

119. Roberds JH, Bishir JW. 1997. Risk analysis in clonal forestry. Can. J. For. Res. 27:425-32

120. Robison DJ. 2002. Deploying pest resistance in genetically-limited forest plantations: developing ecologically-based strategies for managing risk. In Mechanisms and Deployment of Resistance in
Trees to Insects, ed. MR Wagner, KM Clancy, F Lieutier, TD Paine, pp. 16988. New York: Kluwer Acad.

121. Robison DJ, McCown BH, Raffa KF. 1994. Responses of gypsy moth (Lepidoptera: Lymantriidae) and forest tent caterpillar (Lepidoptera: Lasiocampidae) to transgenic poplar, Populus spp., containing a Bacillus thuringiensis $d$-endotoxin gene. Environ. Entomol. 23:1030-41

122. Robison DJ, Raffa KF. 1994. Characterization of hybrid poplar clones for resistance to the forest tent caterpillar. For. Sci. 40:686-714

123. Robison DJ, Raffa KF. 1997. Effects of constitutive and inducible traits of hybrid poplars on forest tent caterpillar feeding and population ecology. For. Sci. 43:252-67

124. Robison DJ, Raffa KF. 1998. Productivity, drought tolerance and pest status of hybrid Populus: tree improvement and silvicultural implications. Biomass Bioenergy 14:1-20

125. Rockwood DL. 1996. Using fastgrowing hardwoods in Florida. Univ. Fla. Coop. Ext. Serv. Fact Sheet EES328.6 pp.

126. Roques A. 1998. Les Curculionidae. In Les Insectes Associes aux Peupliers, ed. A Delplanque, pp. 47-64. Bruxelle: Editions Memor. 350 pp.

126a. Rydelius JA. 1994. Growing Eucalyptus for pulp and energy. In Proc. IEA/BA Task IX, Activity 1 Internat. Conf., ed. BJ Stokes, TP McDonald, pp. 69-74. Auburn, AL: USDA For. Serv., South. For. Exp. Stn. 166 pp.

127. Scarascia-Mugnozza GE, Ceulemans R, Heilman PE, Isebrands JG, Stettler RF, Hinckley TM. 1997. Production physiology and morphology of Populus species and their hybrids grown under short rotation. II. Biomass components and harvest index of hybrid and parental species clones. Can. J. For. Res. 27:28594 
128. Scriber JM, Slansky F Jr. 1981. The nutritional ecology of immature insects. Annu. Rev. Entomol. 26:183-211

129. Shields VDC, Broomell BP, Salako JOB. 2003. Host selection and acceptability of selected tree species by gypsy moth larvae, Lymantria dispar (L.). Ann. Entomol. Soc. Am. 96:920-26

130. Solomon JD. 1979. Cottonwood borer (Plectrodera scalator): a guide to its biology, damage, and control. USDA For. Serv. Res. Pap. SO-157. South. For. Exp. Stn., New Orleans, LA. 10 pp.

131. Solomon JD. 1985. Impact of insects on growth and development of young cottonwood plantations. Res. Pap. SO217. New Orleans, LA: USDA For. Serv., South. For. Exp. Stn. 6 pp.

132. Solomon JD. 1986. Early impact and control of aphid (Chaitophorus populicola Thomas) infestations on young cottonwood plantations in the Mississippi Delta. Res. Pap. SO-326. New Orleans, LA: USDA, For. Serv., South. For. Exp. Stn. 4 pp.

133. Solomon JD. 1995. Guide to insect borers of North American broadleaf trees and shrubs. USDA Agric. Handb. 706. $735 \mathrm{pp}$.

134. Solomon JD, Randall WK. 1978. Biology and damage of the willow shoot sawfly in willow and cottonwood. Ann. Entomol. Soc. Am. 71:654-57

135. Speight MR. 1997. Forest pests in the tropics: current status and future threats. In Forests and Insects, ed. A Watt, N Stork, M Hunter, pp. 83-104. London: Chapman \& Hall

136. Speight MR, Hunter M, Watt A. 1999. Ecology of Insects: Concepts and Applications. Oxford: Blackwell Sci. $360 \mathrm{pp}$.

137. Stanton B, Eaton J, Johnson J, Rice D, Schuette B, Moser B. 2002. Hybrid poplar in the Pacific Northwest. J. For. 100:28-33

138. Stanturf JA, van Oosten C, Netzer DA, Coleman MD, Portwood CJ. 2001. Ecol- ogy and silviculture of poplar plantations. See Ref. 33a, pp. 153-206

139. Stewart JW, Payne TL. 1975. Seasonal abundance and impact of the cottonwood twig borer on cottonwood trees. J. Econ. Entomol. 68:599-602

140. Strauss SH, DiFazio SP, Meilan R. 2001. Genetically modified poplars in context. For. Chron. 77:271-79

141. Strom BL, Hain FP. 1996. Host choice of late instar gypsy moths (Lepidoptera: Lymantriidae) between loblolly pine and sweetgum. Environ. Entomol. 25:60310

142. Strom BL, Hain FP, Ayres MP. 1996. Field performance of $\mathrm{F}_{1}$-sterile gypsy moth larvae (Lepidoptera: Lymantriidae) on loblolly pine and sweetgum. Environ. Entomol. 25:749-56

143. Tharakan PJ, Robison DJ, Abrahamson LP, Nowak CA. 2001. Multivariate approach for integrated evaluation of clonal biomass production potential. Biomass Bioenergy 21:237-47

144. Van Anda KL. 1995. Life history of the scented willow sawfly, Nematus salicisodoratus: preliminary investigations for an integrated pest management program. MS thesis. Wash. State Univ., Pullman. $64 \mathrm{pp}$.

145. Wade MJ, Breden F. 1986. Life history of natural populations of the imported willow leaf beetle, Plagiodera versicolora (Coleoptera: Chrysomelidae). Ann. Entomol. Soc. Am. 79:73-79

146. Wait DA, Jones CG, Coleman JS. 1998. Effects of nitrogen fertilization on leaf chemistry and beetle feeding are mediated by leaf development. Oikos 82:50214

147. Ward KE, Sword Sayer ME. 2004. Susceptibility of potted sweetgum seedlings to insect damage as influenced by fertilization. USDA For. Serv. Gen. Tech. Rep. $S R S-X X$. In press

148. Warren LO. 1957. Notes on the biology of a sawfly, Nematus salicis-odoratus Dyar. J. Kans. Entomol. Soc. 30:11-12 
149. White JA, Whitham TG. 2000. Associational susceptibility of cottonwood to a box elder herbivore. Ecology 81:1795803

150. With KA. 2002. The landscape ecology of invasive spread. Conserv. Biol. 16:1192-203

151. Witter JA, Mattson WJ, Kulman HM. 1975. Numerical analysis of forest tent caterpillar (Lepidoptera: Lasiocampidae) outbreak in northern Minnesota. Can. Entomol. 107:837-54

152. Deleted in proof

153. Young W. 1998. The Domtar experience. Proc. 1998 Annu. Meet. Poplar Counc.
Can., 21-24 Sept., Sainte-Foy, Quebec. $28 \mathrm{pp}$.

154. Zhong C, Ellar DJ, Bishop A, Lin S, Hart ER. 2000. Characterization of a Bacillus thuringiensis $\delta$-endotoxin which is toxic to insects in three orders. J. Invert. Pathol. 76:131-39

155. Zsuffa L, Sennerby-Forse L, Weisgerber H, Hall RB. 1993. Strategies for clonal forestry with poplars, aspens, and willows. In Clonal Forestry. II. Conversion and Application. Genetics, Biotechnology, and Application, ed. MR Ahuja, WJ Libby, pp. 91-119. Berlin: SpringerVerlag 